\title{
COVID-19 and the repercussions of the closing of decentralised slot machines and gambling arcades in Finland in 2020 and 2021
}

\author{
Riitta Matilainen
}

This non-peer reviewed entry is published as part of the Critical Gambling Studies Blog. Visit an interactive version of this blog at: https://criticalgamblingstudies.blogspot.com/2021/07/covid-19and-repercussions-of-closing.html

\section{COVID-19 and other restrictions on gambling on slot machines}

Finland is a small Nordic welfare state with a population of 5.5 million that is among the biggest gambling nations in the world and that has the only gambling monopoly in the European Union. Due to the COVID-19 pandemic (and without historical precedent), Veikkaus (Finland's gambling monopoly holder) shut down both decentralised slot machines and gambling arcades on March 13, 2020. They re-opened the gambling arcades in June 2020 and the decentralised slot machines in midJuly 2020. As the infection rates rose again, Veikkaus closed its decentralised slot machines and arcades in November-December 2020 in the health care districts where the Covid-19 pandemic was accelerating (most of Finland). At the time of writing, decentralised slot machines, gambling arcades and the casino are again open. ${ }^{1}$

In this blog, I ask what happened when COVID-19 forced the shutdown of both decentralised slot machines and slot machines in gambling arcades and in a casino in a gambling culture that has been accustomed to slot machine gambling for almost a century?

I discuss the repercussions of these closures for recreational gamblers, at risk and problem gamblers and their significant others, the gambling monopoly holder Veikkaus, the different stakeholders, and the Finnish state which is heavily dependent on Veikkaus' profits. I also ponder the possibility of whether there is something to be learnt from these closures from the perspective of gambling researchers and gambling harm prevention internationally.

My blog is based on various sources, including Finnish Association for Substance Abuse Prevention (EHYT) opinion polls (one statistically representative research survey done by Finnish market research company Taloustutkimus in the spring of 2020 and two online polls done in the springs of 2020 and 2021), print media and social media analysis, Veikkaus' information on the changes of gambling behaviour during the COVID-19 pandemic, Finnish Institute for Health and

\footnotetext{
${ }^{1}$ At the same time but not due to COVID-19, the number of decentralised slot machines was reduced from 18500 to 10400 (40\% reduction). Furthermore, the hours of decentralised slot machines were reduced so that they opened only at 11 am and were closed by $4.00 \mathrm{am}$.
} 


\section{Critical Gambling Studies Blog}

Welfare's (THL) and Peluuri's report on gambling in Finland during COVID-19 pandemic, and academic research.

\section{What you need to know about the history of slot machines in Finland}

I dealt with the question of Finnish gambling culture's peculiarities extensively in my PhD research, and here I draw on that research to highlight a few relevant aspects of this history (Matilainen, 2017). One of the things that makes Finnish gambling culture interesting in the international comparison is the profusion of all kinds of gambling venues across the country. However, it is the abundance of slot machines placed in everyday consumption places, such as grocery stores, service stations, cafes, and kiosks, that is most exceptional (Matilainen, 2017). These slot machines are called decentralised slot machines in this text. At the time of writing (June 2021) there are 10,400 decentralised slot machines, and 2750 slot machines in gambling monopoly holder Veikkaus' own gambling arcades and in a casino in Helsinki.

Slot machines were introduced in Finland in the 1920 s by private entrepreneurs of German descent, and most of the first slot machines were also bought from Germany. However, the regulation of slot machines was slowly tightened in the 1920s and 1930s, culminating in the founding of a monopoly, Finnish Slot Machine Association (RAY), by charitable associations and associations endorsing national defence in 1938, thus eliminating all the private and foreign influences from the slot machine business. It was only in 1946 that slot machines were allowed into all restaurants, pubs, and cafés. This decision was made to boost profits and it meant that people living in the countryside (most Finns) and working-class people could now try their luck with the legendary Finnish mechanical slot machine Payazzo. Payazzo became an essential part of the coffee bar milieus in the Finnish countryside to the extent that from the 1950s onwards it was culturally almost impossible to picture a bar without a group of men fiddling around a Payazzo and without the jingle of coins won (Matilainen, 2017).

In the 1970s, RAY decided that the time was right to place slot machines in locations other than restaurants, cafés, and pubs. According to RAY, such a change in policy was possible because attitudes towards gambling had changed and the standard of living, as well as the supply of other gambling games, had increased. The new slot machine locations were waiting halls, canteens, service stations, kiosks, department stores, bingo halls, amusement spaces, ferries, and ships, as well as various exhibitions and fairs. The supply of slot machines was diversified in 1977, as RAY was given a permanent permit to operate fruit slot machines. Slot machines became a ubiquitous phenomenon in Finnish society, and a part of the everyday lives of Finns. It was during the severe economic depression of 1990s that the number of slot machines grew significantly as the Finnish state desperately wanted more funding (Matilainen, 2017).

Today all slot machines are owned by the Finnish gambling monopoly holder Veikkaus. There are almost no illegal slot machines. Decentralised slot machines have been a target of feverish societal discussion on both media and social media during the past decade or so and for good reason. One of the biggest problems has been underage gambling. Despite supervision by staff at the various venues that house slot machines, youngsters have been able to play the slot machines quite widely. It was only in 2011 that the 18-year age limit came into force for all forms of gambling (including also decentralised slot machines, where the previous age limit was 15 years). Decentralised slot machines 


\section{Critical Gambling Studies Blog}

have historically caused most gambling harm and gambling problems in Finland, making it difficult for those recovering from problem gambling to go about their daily business. It has also been proven by researchers that more slot machines have been located in socio-economically less advantaged areas (Raisamo \& al., 2019).

I have stated that the growth and taming of gambling has been extremely successful in Finland (Matilainen, 2017). Things are changing rapidly as Finland is now following in the footsteps of many other European countries and tightening its regulations to prevent gambling harm more efficiently, partly as a result of societal discussion on gambling harm.

\section{Recreational gamblers, at risk and problem gamblers, and significant others}

As noted in the introduction, the COVID-19 pandemic resulted in unprecedented closures of Finnish decentralised slot machines and gambling arcades. Many recreational gamblers reduced their gambling especially during the first lockdown of spring 2020 as frequency of grocery shopping and working in an office decreased. Many recreational gamblers used less money in gambling than before (Taloustutkimus, 2020).

Most importantly, there does not seem to have been a major transition from land-based gambling to online gambling, either offered by gambling monopoly holder Veikkaus or by the many online gambling companies outside the gambling monopoly (Taloustutkimus, 2020; EHYT online polls, 2020 $\& 2021)$. Veikkaus reports that average weekly player numbers of the digital Casino Games increased by $7.4 \%$ in 2020 in comparison to 2019 but the total gross gaming revenue remained at almost the same level as in 2019. Veikkaus' digital Casino Games did temporarily attract more players after the land-based slot machines were closed. In March and April 2020, the number of weekly players in the digital channel went up by $21 \%$ as compared with the respective period in 2019 . The customer numbers increased again at the end of 2020 as the slot machines were partly closed in late November. The weekly number of customers in the digital channel rose by c. $15.2 \%$ at this point in comparison to the respective period in 2019 (Veikkaus, 2020).

Many at-risk and problem gamblers were relieved when decentralised slot machines were closed. They stated that they could now do their grocery shopping without stress, and money usually spent on slot machines could be used to buy necessities like food (EHYT online polls in 2021 \& 2021). Peluuri (which is a Finnish helpline offering support for gambling problems) stated in its Annual Report 2020, that due to COVID-19 and the extensive closure of decentralised slot machines contact with Peluuri decreased (especially from people dealing with problem gambling on land-based slot machines) (Silvennoinen \& Vuorento, 2021).

In the Finnish Gambling population study, $21 \%$ of the respondents (approximately 790,000 people) reported having one or more significant others who had a gambling problem (Salonen et al., 2020). Polarization of those experiencing gambling harm and gambling problems was also visible in the online poll EHYT conducted on significant others of gamblers in the spring of 2021. In other words, some gamblers had paused gambling due to shutting down of decentralised slot machines but some had more opportunities to gamble because of distant work or redundancy and furloughs. Many 


\section{Critical Gambling Studies Blog}

significant others wanted to get help for the gamblers and for themselves. They were frustrated that help was not easily available due to the COVID-19 pandemic.

\section{Veikkaus, stakeholders, and the Finnish state}

Veikkaus' profit for the financial year of 2020 was EUR 680.2 million (-32.6\%). The profit from the gaming operations, i.e., the gross gaming revenue for the financial year of 2020 was EUR 1,260.3 million (-25.5\%). Slot machines generated 299 million EUR (24\% of GGR) in 2020, whereas in 2019 they generated 683 million EUR (40\% of GGR). COVID-19 pandemic reduced Veikkaus' gross gaming revenue by more than EUR 300 million in 2020.

COVID-19, together with Veikkaus' responsible gambling measures have made it impossible for Veikkaus to generate revenue at the expected/needed level, so the funding received by beneficiaries from gambling proceeds has diminished. This causes uncertainty about the future of civil society in which (NGOs) and other beneficiaries like sports, arts, science, and youth services are supported by gambling funds. A working group with representatives from all of the government parties published its report on the future of possibly placing gambling proceeds within the state budget (Finnish Government, 2021b). Stated bluntly, the COVID-19 pandemic has called into question the legitimacy of Veikkaus and its monopoly since it cannot produce sufficient revenue.

Closing of decentralised slot machines has been praised on social media by experts and people who have experienced or who are experiencing gambling harm and gambling problems. German-based grocery store chain Lidl decided to remove all the slot machines from their stores in Finland. The decision was big news in traditional and social media and widely debated, marking a change in the policies of grocery store chains towards slot machines.

The responses to COVID-19 (shutting down of slot machines, plexiglass dividers between slot machines, lowering the loss limits of Veikkaus' fast-paced gambling games, etc.) can be interpreted as signs of the state stepping in and protecting its citizens. Historically, the state has been able to trust that Veikkaus will produce more revenue every year to be distributed to beneficiaries. This funding has been an important part of the financing of the Finnish welfare state (Matilainen, 2017). As I have pointed out, this has now fundamentally changed. The role of Veikkaus must be reinvented.

\section{Opinions on keeping decentralised slot machines shut after COVID-19}

Opinion on whether to keep the decentralised slot machines shut even after the pandemic is over does not seem to have changed during the COVID-19 year. According to EHYT's online poll during spring 2021, 40\% ( $n=74)$ of gamblers would like to have the decentralised slot machines shut also after the COVID-19 pandemic whereas $27 \%(n=51)$ would like to see them open again. $21 \%(n=40)$ could not express their opinion on the matter and $9 \%(n=17)$ suggested something else. This distribution of opinions is strikingly like an online poll EHYT made during spring 2020 when the slot machines were closed for the first time. It is interesting that the public opinion barely changed even though the slot machines were closed for what is historically a long time. 


\section{Critical Gambling Studies Blog}

\section{What happens next?}

Compulsory authentication of players' identity covering slots gambling was introduced to decentralised slot machines in January 2021. Veikkaus will also adopt compulsory authentication in its gambling arcades in July 2021. This means that players have a chance to set a complete ban on their gambling if they wish. The aim is also to root out underage gambling which has been a problem so far.

A reformation of the Lotteries Act is planned to come into effect in 2022. For the first time, it has been publicly acknowledged that prevention of harm must be considered when placing slot machines in public and commercial spaces. Veikkaus and the establishments providing space for slot machines are to be required to take account of principles for preventing the harm caused by gambling and to draw up a related plan. Minors and otherwise vulnerable persons are to be protected in particular by this reform. What this means in practice remains to be seen.

\section{What can be learnt from the Finnish case?}

First and foremost, unforeseen circumstances offer a great opportunity for comparative research. It is important to gather reliable information before and after major social and economic changes and analyse it to steer the regulation of gambling to avoid financial, social, and emotional hardship for the population.

Other important questions are raised by the Finnish case, including: What happens with the prevention of gambling harm if most gamblers gamble the same or even reduce their gambling engagement, but a minority of gamblers experience significantly more harm? How can we prevent further polarization of gambling behaviour in a situation where most of the health care and NGOs work under enormous pressure? Unfortunately, I have no definite answers to give yet but what we have learnt is that the funding of NGOs and other important institutions such as art, science, sports, and youth work should not be solely dependent on revenues from the gambling sector.

We also learned that substitution of slot machine gambling by online gambling did not seem to happen in the Finnish context at least to the extent that was expected when the COVID-19 pandemic started. What is it within the Finnish slot machine gambling culture that resists change? This is a question that needs to be studied further but I suspect that the answer lies in the gambling culture that has taken root over the decades. This is why we should be more aware of the historical discourses and practices that have shaped our gambling cultures into what they are today. Each gambling culture is unique and should be studied as such. The Finnish slot machine scene reminds us of that maxim.

My research found that within Finnish gambling culture, playing with slot machines is commonplace for many people. It is something they can do in moderation after they buy their groceries or fuel their cars. They do not care for it so much they would go through the hassle of playing online; rather slot machine gambling is anchored in a certain place after certain other events. One should also not underestimate the power of social interaction while playing slot machines for recreation; for many, gambling is a shared social event. To fully understand why some things changed and others stayed the same notwithstanding the shocks of COVID-19 it is important to do research on socio-cultural aspects of the gambling phenomenon beyond problem gambling. It remains to be seen how COVID- 


\section{Critical Gambling Studies Blog}

19 impacts the legitimacy of the Finnish gambling monopoly and whether the experiences of temporary closings of decentralized slot machines will have a permanent mark on the Finnish gambling policy and culture or will the closings be just an interesting footnote in the work of future historians of gambling.

Riitta Matilainen has a PhD in social sciences from the University of Helsinki, Finland (2017). She is an economic and social historian who specializes in the history of gambling and in the methodological questions concerning class and gender in gambling studies. Her latest article written together with $\mathrm{PhD}$ Maria Heiskanen dealt with the Finnish baby boomer generation as gamblers and how to prevent and recognize gambling harm that they experience with the help of intersectional approach. Riitta currently works as a Head of Gambling Harm Prevention Unit at EHYT Finnish Association for Substance Abuse Prevention.

\section{References}

Finnish Government. (2021a, January 7). Ministry of the Interior. Proposal for reforming Lotteries Act sent out for comments. [News release.] https://valtioneuvosto.fi/en/-/1410869/proposal-for-reforming-lotteries-act-sent-outfor-comments

Finnish Government. (2021b, February 26). Ministry of Education and Culture. Working group: Placing gambling proceeds within the Budget and beneficiaries under the spending limits procedure. [News release.] https://minedu.fi/en/-/working-group-placing-gambling-proceeds-within-the-budget-and-beneficiaries-underthe-spending-limits-procedure

Finnish Government. (2020, April 30). Ministry of the Interior. Loss limits for Veikkaus Oy's online gambling to be lowered. [News release.] https://valtioneuvosto.fi/en/-//1410869/netissa-pelattavien-veikkaus-oy-n-rahapelientappiorajoja-lasketaan

Matilainen, R. (2017). Production and consumption of recreational gambling in twentieth-century Finland. [Dissertation.] University of Helsinki. https://helda.helsinki.fi/bitstream/handle/10138/226022/PRODUCTI.pdf?sequence=1\&isAllowed=y

Raisamo, S., Toikka A., Selin, J., \& Heiskanen, M. (2019). The density of electronic gambling machines and arealevel socioeconomic status in Finland: A country with a legal monopoly on gambling and a decentralised system of EGMs. BMC Public Health 19, 1198. https://doi.org/10.1186/s12889-019-7535-1

Salonen, A., Hagfors, H., Lind, K., \& Kontto, J. (2020). Gambling and problem gambling - Finnish gambling 2019. Study by Finnish Institute for Health and Welfare, commissioned and financed by Ministry of Social Affairs and Health.https://www.julkari.fi/bitstream/handle/10024/139651/SR2019 tilastoraportti\%20englanniksi\%20200420 20 final $\% 20 \% 282 \% 29$.pdf? sequence $=1 \&$ is Allowed $=y$

Silvennoinen, I. \& Vuorento, H. (2021). Peluuri Annual Reports 2020. https://www.peluuri.fi/peluuri/peluurinvuosiraportit (Summary in English)

Veikkaus. (2020). Annual and sustainability report 2020. https://cms.veikkaus.fi/site/binaries/content/assets/dokumentit/vuosikertomus/2020/annual csrreport 2020.pdf

Finnish Association for Substance Abuse Prevention EHYT's blogs and press releases related to gambling and COVID-19 Internet polls and survey (in Finnish only): 


\section{Critical Gambling Studies Blog}

Korona-ajan rahapelaamisessa viitteitä kahtiajakautumisesta: Koronaväsymys syventää rahapelihaittoja ja ongelmia Korona-ajan rahapelaamisessa viitteitä kahtiajakautumisesta: Koronaväsymys syventää rahapelihaittoja ja -ongelmia | EHYT ry

Korona-aika ei juuri muuttanut suomalaisten rahapelaamista - entä tulevaisuudessa? https://ehyt.fi/uutishuone/blogit/korona-aika-ei-juuri-muuttanut-suomalaisten-rahapelaamista-entatulevaisuudessa/

Korona-aika tuonut rahapelaajien läheisille sekä helpotusta että ahdistusta https://ehyt.fi/uutishuone/uutiset/korona-aika-tuonut-rahapelaajien-laheisille-seka-helpotusta-etta-ahdistusta/ Blogi: Korona-ajan vaikutukset rahapelaajiin ja heidän läheisiins https://www.ept-verkosto.fi/blog-post/blogikorona-ajan-vaikutukset-rahapelaajiin-ja-heidan-laheisiinsa/

Rahapeleihin käytetty rahan määrä pysyi samana tai väheni poikkeusaikana https://ehyt.fi/uutishuone/blogit/rahapeleihin-kaytetty-rahan-maara-pysyi-samana-tai-vaheni-poikkeusaikana/

Poikkeusajan hiljaiset signaalit: Alkoholi ja rahapelaaminen https://ehyt.fi/uutishuone/blogit/poikkeusajanhiljaiset-signaalit-alkoholi-ja-rahapelaaminen/

Nettikysely: "Ei kulu raha peleihin kun ei ne toimi" - korona-aika on muuttanut rahapelaamista https://ehyt.fi/uutishuone/tiedotteet/nettikysely-ei-kulu-raha-peleihin-kun-ei-ne-toimi-korona-aika-onmuuttanut-rahapelaamista/

Pitäisikö hajasijoitetut rahapeliautomaatit pitää suljettuina myös korona-ajan jälkeen? https://ehyt.fi/uutishuone/blogit/pitaisiko-hajasijoitetut-rahapeliautomaatit-pitaa-suljettuina-myos-koronaajan-jalkeen/

Kyselytutkimus: Rahapelien pelaaminen on vähentynyt selvästi poikkeustilan aikana https://ehyt.fi/uutishuone/tiedotteet/kyselytutkimus-rahapelien-pelaaminen-on-vahentynyt-selvastipoikkeustilan-aikana/

Taloustutkimus. (2020). Taloustutkimus: Poikkeustilan aiheuttamat muutokset rahapelaamisessa.

Tutkimusraportti/EHYT ry. 27.4.2020. https://ehyt.fi/wp-content/uploads/2020/08/Taloustutkimus Muutoksetrahapelaamisessa Raportti 042020 s.pdf 